\title{
How to Open an Academic Department
}

\author{
Farhad Dastur
}

Kwantlen Polytechnic University, farhad.dastur@kpu.ca

\section{Editors' Commentary}

Despite its wide-ranging benefits, the philosophy of Open represents change and, as a result, can easily threaten those who wish to maintain the status quo. In this chapter, author Farhad Dastur provides an insightful glimpse into a process of cultural change within an academic department-an organizational unit that he argues is effectively designed to resist change. In doing so, he provides a set of three practical recommendations for those interested in fostering change, including encouraging a departmental culture of openness, focusing on the quality of $O E R$, and encouraging departmental control over OER.

'A ship in harbor is safe - but that is not what ships are built for.' -John A. Shedd ${ }^{1}$

\section{Introduction}

This is the inside story of how my psychology department opened itself to the principles, practices, and possibilities of open education. We are two years into that story and far from finished. Nonetheless, I think this is a good time to pause, reflect, and share some insights that may help you as an agent of openness in your department.

Open education has the potential to transform the way we teach. ${ }^{2}$ Unleashing that potential is imperative, but transforming complex institutions resistant to change is a wicked problem. ${ }^{3}$ Universities have been around for almost a

How to cite this book chapter:

Dastur, F. 2017. How to Open an Academic Department. In: Jhangiani, R S and Biswas-

Diener, R. (eds.) Open: The Philosophy and Practices that are Revolutionizing Education and Science. Pp. 163-178. London: Ubiquity Press. DOI: https://doi. org/10.5334/bbc.m. License: CC-BY 4.0 
millennium and that persistence speaks to their remarkable immunity to new ideas and practices. Open education takes the spirit of sharing, creativity, and transparency and leverages those attributes with the flattening capabilities of the Internet, the portability of mobile computing, and the wider freedoms of flexible copyright and copyleft to achieve dramatic improvements in accessibility, content control, and creative collaboration. Against such lofty premises and promises, why has academia not embraced open education?

The answer requires an understanding of academic resistance to change. I propose just such an understanding: a theory born out of 15 years of observations as an educator, scholar, and academic administrator at Kwantlen Polytechnic University (KPU) in Vancouver, Canada. I conceptualize resistance as a structural phenomenon designed to protect the stability, integrity, and viability of academic departments and the faculty they serve. Complicating this conceptualization is the idea that organizations faced with transformative change are best understood as complex adaptive systems where the parts interact in unexpected ways. Linear prediction models are inappropriate in such systems; however, retroactive pattern sensing is possible. ${ }^{4}$ With that in mind, I offer three pattern-based recommendations for opening your psychology department, namely, (1) encourage a departmental culture of openness; (2) focus on quality open educational resources (OER); and (3) encourage departmental control over OER.

\section{Why Open?}

Too many universities, and academic departments in particular, are closed in a world of blissful insularity, disciplinary elitism, strange and archaic traditions, reputational competitiveness, ivory tower detachment, ingroup vs. outgroup mistrust, resource competition, and epistemic fundamentalism. ${ }^{5}$ This is the way it has been for much of the past thousand years. Indeed, so deeply are these features embedded into the fabric of our academic existence, that it is not uncommon to encounter colleagues who question whether this is even a problem. From the time we were undergraduates, through the long years of graduate training, and then as the professoriate class, we were all indoctrinated into the rigid rules and cultural codes of an institution older than the Crusades. Indeed, even the Collegiate Gothic architecture and religious iconography of many of North America's universities betray an Oxbridgian-inspired aesthetic preoccupation with gravitas, abiding permanence, and medieval heritage. ${ }^{6}$

Openness is grounded in the Enlightenment ideals of liberalism, freedom, citizenship, social progress, and transformation. ${ }^{7}$ These ideals inform the open education, open access, open source, open science, open data, open design, and open government movements. For a summary of the contrasts between open and traditional education see the excellent chapter by Huitt \& Monetti in this book. When I discovered open education-astonishingly late in my career-I 
recognized these ideals as the same ones I had always held as an educator, scientist, and citizen. I became a scientist because of a burning curiosity about the world; I became an educator because of an irrepressible desire to share that curiosity and the knowledge it led to. In that sense, my interest in openness was less like learning and more like remembering. A recollection of a time when the pursuit of knowledge was unmediated by formal education, unfettered by ideologies, and unencumbered with fears of failure, criticism, or dark sarcasm in the classroom. I still remember that evening in my childhood when I first saw Saturn and its rings through a telescope. All the fascinating astronomy I have learned since does not rival the purity and stillness of that perfect moment. That, too, is openness.

\section{A Theory of Departmental Resistance to Change}

My unit of analysis in understanding resistance to change is the academic department: the organizational unit primarily constituted by faculty, organized by discipline, and having significant control over disciplinary matters like curriculum. Departments represent the collective will of individual faculty in a given discipline (more on this fiction later). Much has been written on individual faculty resistance to change as well as institutional barriers to change. ${ }^{8}$ Hopefully, my focus on the department offers different and useful insights.

The earliest medieval universities taught the Trivium and the Quadrivium; modern universities teach Nanotechnology, Postcolonial Literature, and myriad other courses. Though the courses have changed, universities' fundamental structures, governance models, and isolationist tendencies persist. For more than $95 \%$ of their history, universities were tasked with knowledge transfer from master to student. The hierarchical, parochial, and oligarchic governance and organizational structures that emerged over those centuries are still largely in play. This is either a fact of stunning consistency or appalling inflexibility. In his 1963 classic, The Uses of the University, Clark Kerr (2001: 115) observed that some 85 institutions in the Western world established by 1520 still existed in recognizable form and function including the Catholic Church, the British and Icelandic Parliaments, several Swiss cantons, and 70 universities.

'Kings that rule, feudal lords with vassals, and guilds with monopolies are all gone. These seventy universities, however, are still in the same locations with some of the same buildings, with professors and students doing much the same things, and with governance carried on in much the same ways.'

Academic departments value tradition, reputation, autonomy, and disciplinary purity. ${ }^{9}$ How many successful interdisciplinary programs exist at your institution? I recall a Faculty-wide curriculum committee meeting where a respected historian announced that only History's courses should be allowed to use the 
word 'history' in their titles. I've seen departments form alliances of solidarity when faced with the latest outrageous policy proposal from the Dean's Office, only to quietly form 'an understanding' with that same ambassador of 'The Dark Side' when seeking greater autonomy, resources, or preferential treatment.

Academic departments resist new ideas because they are designed to do so. It is no small irony that this happens in the very abodes where scholars tirelessly generate new ideas. However, new ideas when applied to departments signal a threat to the department's stability, interests, and self-preservation instincts. Like organisms striving to survive in a world full of change, challenge, and chaos, organizations are complex adaptive systems striving to survive their environmental vicissitudes. Several mechanisms exist for opposing change including procedural tactics at meetings; sending proposals for further study (read strangulation); writing letters of protest to the Dean; filing union grievances; finding common cause with similarly affected departments; and invoking a Fear, Uncertainty, and Doubt (FUD) campaign by suggesting that the change will threaten autonomy, job security, academic freedom, program quality, or institutional reputation.

An analogy drawn from immunology and informed by signal detection theory ${ }^{10}$ may shed light into the nature of this change resistance. Consider how harmful antigens (e.g., bee venom) often trigger an antibody response that then neutralizes the antigen. I argue that new ideas, initiatives, and proposals are the antigens that trigger a departmental immune reaction. Think budget cuts or policy edicts from Administration that weaken departmental control. In an allergic reaction, the immune system is inappropriately triggered by harmless antigens (e.g., pollen). Symptoms like inflammation, sneezing, and tearing eyes follow. This reaction is called a false positive or Type I error: an inappropriate response to a non-existent threat. The opposite error, in which the immune system fails to respond to harmful substances, is a false negative or Type II error. Departments make false positive errors when they reflexively reject new ideas, initiatives, and policies. They make false negatives when they fail to respond to real threats. Figure 1 displays these four decision-making possibilities.

Which decision-making error is worse depends on what kind of organization you are and the nature of the threat. In organizations where stability and

\begin{tabular}{|c|c|c|}
\cline { 2 - 3 } \multicolumn{1}{c|}{} & $\begin{array}{c}\text { DEPT REJECTS } \\
\text { IDEA }\end{array}$ & $\begin{array}{c}\text { DEPT FAILS TO } \\
\text { REJECT IDEA }\end{array}$ \\
\hline BAD IDEA & $\begin{array}{c}\text { Correct } \\
\text { Decision }\end{array}$ & $\begin{array}{c}\text { False Negative } \\
\text { (Type II Error) }\end{array}$ \\
\hline GOOD IDEA & $\begin{array}{c}\text { False Alarm } \\
\text { (Type I Error) }\end{array}$ & $\begin{array}{c}\text { Correct } \\
\text { Rejection }\end{array}$ \\
\hline
\end{tabular}

Fig. 1: Signal detection theory as applied to academic decision-making. 
tradition are prized-universities for most of their +900 -year-old history-we expect to see resistant decision-making that opposes most ideas (i.e., few false negatives and lots of false positives). The logic of this bias is that the consequences of failing to detect and respond to truly threatening ideas are far worse than the consequences of rejecting good ones.

Things began to fall apart in the 1960s. Universities had to contend with the unrest of the counterculture movement, the New Left, distorting marketplace influences, shifting societal expectations, and an increasingly technological and globalized world. Universities evolved into complicated and complex communities re-tasked with becoming transformative learning organizations that embrace change, serve society, and respond with agility to emerging opportunities. The governance models, power hierarchies, and pedagogical models that served them so well for the past nine centuries, now risked becoming the instruments of their own decline. The reflexive resistance to new ideas embedded into the DNA of departmental culture served well in maintaining a business-as-usual enterprise. But today business is unusual. Now, for perhaps the first time in history, a closed academic department is at risk of becoming a closed academic department.

\section{Recommendation 1: Encourage a Departmental Culture of Openness}

'The politics of the university are so intense because the stakes are so low.'

$$
\text { -Wallace Sayre }{ }^{11}
$$

In the spring of 2014, my colleague Rajiv Jhangiani, one of open education's most passionate advocates, challenged our department to embrace open education. In response, our departmental Teaching Excellence committee decided to discuss what all the fuss was about. My home was volunteered for the meeting. Over cups of French-pressed coffee and slices of freshly baked cake, we held our first open education kaffeeklatsch [kä-fē-, -kläch. noun. German, from Kaffee coffee + Klatsch gossip]. In retrospect, I consider this gathering the founding event in the project and process of opening our department.

In the two years since, we have made remarkable progress. Table 1 provides a timeline of developmental landmarks in the opening of our department. These landmarks span several themes including open education advocacy, teaching, research, presentations, course development, committee formation, policy review, and OER development.

I mentioned the kaffeeklatsch because the simple act of breaking bread during a meeting in a colleague's home is not so simple for some departments. As a naïve associate dean, I noticed departments divide into dueling dualities of sub-disciplines: Experimental vs. Clinical Psychology; Physical vs. Human 


\begin{tabular}{|c|c|}
\hline DATE & DEVELOPMENTAL LANDMARKS \\
\hline April, 2014 & Kaffeeklatsch to discuss OER adoption \\
\hline July, 2014 & $\begin{array}{l}\text { Faculty from six universities in BC create } 851 \text { test bank } \\
\text { questions during a } 2 \text { day Test Bank Sprint funded by BCcampus } \\
\text { and NOBA }\end{array}$ \\
\hline October, 2014 & $\begin{array}{l}\text { Symposium presentation at the Society for the Teaching of } \\
\text { Psychology's Annual Conference on Teaching }\end{array}$ \\
\hline November, 2014 & Formation of a departmental OER Committee \\
\hline May, 2015 & $\begin{array}{l}\text { Faculty member gives the keynote at the Open Textbook } \\
\text { Summit }^{13}\end{array}$ \\
\hline July, 2015 & $\begin{array}{l}\text { Presentation of faculty-led research at the 5th Vancouver } \\
\text { International Conference on the Teaching of Psychology }{ }^{14}\end{array}$ \\
\hline October, 2015 & $\begin{array}{l}\text { Faculty member (Levente Orban) begins work on a PsycWiki } \\
\text { site including server installation and software configuration }\end{array}$ \\
\hline October, 2015 & Two faculty present at Open Access Week \\
\hline November, 2015 & $\begin{array}{l}\text { Presentation of faculty-led research at the OpenEd } 2015 \\
\text { Conference }^{15}\end{array}$ \\
\hline October, 2015 & $\begin{array}{l}\text { Two psychology faculty begin developing the WikiEducator- } \\
\text { based open course, Introduction to Psychology for the Open } \\
\text { Educational Resources Universitas (OERu) }\end{array}$ \\
\hline December, 2015 & $\begin{array}{l}\text { Two psychology faculty join the institution-wide Open Studies } \\
\text { Working Group }\end{array}$ \\
\hline January, 2016 & $\begin{array}{l}\text { Launch of the department's Introductory Psychology OER } \\
\text { Moodle website (Developers: David Froc, Richard Le Grand, \& } \\
\text { Kurt Penner) }\end{array}$ \\
\hline January, 2016 & $\begin{array}{l}\text { OER Committee suggests ending the practice of using only one } \\
\text { textbook for all sections of Intro Psychology and recommends } \\
\text { that instructors be free to use either one traditional textbook or } \\
\text { any open textbook }\end{array}$ \\
\hline January, 2016 & $\begin{array}{l}\text { KPU becomes the first institution in BC to have over } 100 \text { course } \\
\text { adoptions of open textbooks with a total cost savings to students } \\
\text { of US } \$ 231,264\end{array}$ \\
\hline February, 2016 & $\begin{array}{l}\text { The Kwantlen Psychology Student Society attends a department } \\
\text { meeting and urges faculty to consider adopting open textbooks } \\
\text { when feasible }\end{array}$ \\
\hline
\end{tabular}

Table 1: Developmental Landmarks in the Opening of Psychology at Kwantlen Polytechnic University. 
Geography; East Asian vs. South Asian Studies; and so on. Anthropology, once married to Sociology, now lived as a divorcée department with seven dependent members. Some departments refused to elect a chair. One historian refused to speak to another, while one criminologist ought to have refused to speak to another. Closed departments arise out of real or perceived mistreatment, toxic personalities, demoralizing budget cuts, ideological differences, incompetent leadership, competition for limited office and research space; and biased hiring decisions. And the situation at KPU is far from unique.

Academic tribalism replicates itself, fractal-like, up and down the institutional scale. Within psychology there are cognitive folks who look down on the personality folks. I've spoken to esteemed honeybee researchers that refused to speak to each other because of a bitter disagreement over which theory of colour vision best explained honeybee vision. And whom among us does not have a position on the qualitative/quantitative methodological divide or the tiresome nature/nurture debate?

Many formal and informal practices go into creating a transparent, collegial, collaborative, and healthy workplace. Here are some that characterize our department. On the whole, our department meetings are well run, often ending with faculty sharing a pint at a local pub. Faculty accomplishments are acknowledged in emails, at meetings, and in the departmental newsletter. An annual family-friendly retreat helps to build bonds of trust and future collaboration. Faculty provide input into the educational plan. Collegiality is a consideration in hiring decisions. One faculty member organizes the Vancouver International Teaching of Psychology Conference while another takes a lead organizing the Connecting Minds Psychology Undergraduate Research Conference. Faculty and students volunteer at both events. Mentorship is available for new faculty members to help them navigate the complexities of their budding academic careers. Pitched battles pitting faculty against students have played out on the badminton court, baseball field, and bowling alley. Intriguingly, recent research also suggests that the personality trait called openness to experience is positively correlated with faculty members' propensity to both create and adapt OER. ${ }^{16}$

Coming full circle, my first recommendation on how to open a psychology department is to first foster an open departmental culture. Create a culture where trust, communication, resiliency, and collegiality are the norm and watch your department show signs of spontaneous opening. And while that happens, please be sure to serve good coffee.

\section{Recommendation 2: Focus on Quality Open Educational Resources}

One of the biggest barriers to OER adoption, and open textbook adoption in particular, is the perception of inferior quality. ${ }^{17}$ In one survey, 95\% of Berkeley faculty identified 'Quality of content, including editorial review' as a necessary 
condition for open textbook adoption. ${ }^{18}$ Reassuringly, the studies on faculty perceptions reveal that OER are typically viewed as equivalent in quality to traditional textbooks. ${ }^{19}$

When choosing a textbook, faculty decision-making is informed by several criteria including:

(a) The quality, readability, and organization of content.

(b) The ease of the adoption process.

(c) The quality and appeal of the illustrations and graphics.

(d) The types of ancillary supporting materials like test banks, PowerPoint slides, and Instructor's Manuals.

(e) The reputation of the author(s).

In terms of the latter, most psychology faculty would view favourably the traditional textbook, Psychology, authored by Harvard's Daniel Schacter, Daniel Gilbert, Daniel Wegner, and Matthew Nock (2014). How could an open textbook compete with such high caliber authors or, for that matter, with the power, prestige, and deep pockets of its dark overlord, Worth Publishers?

Ed and Carol Diener have an answer. The Diener's NOBA project ${ }^{20}$ has developed an Introduction to Psychology OER with content modules written by widely respected scholars like Elizabeth Loftus, ${ }^{21}$ Ed Diener, ${ }^{22}$ Peter Salovey, ${ }^{23}$ Roy Baumeister, ${ }^{24}$ Henry L. Roediger III, ${ }^{25}$ and David Buss. ${ }^{26}$ Interested? And what if I told you that the online version of this OER was free and would save your students thousands of dollars? But wait, that's not all. If you adopt this OER right now, you will also receive a Creative Commons Attribution-NonCommercial-ShareAlike license that permits the copying and redistribution of the content in any medium or format, and permits content adaptation, modification, and remixing for educational purposes. ${ }^{27}$ Your only obligations are to give appropriate credit, provide a link to the license, indicate if you made any changes, and promise not to make a profit from the material.

Making faculty in my department aware that high quality OER already exist (e.g., NOBA, OpenStax, BCcampus); that they had been written and reviewed by recognized faculty; and that they are easy to access, helped overcome legitimate concerns about OER quality. Over the period 2013-2015, the percentage of our faculty teaching Introductory Psychology with an open textbook increased from $0 \%$ to $20 \%$.

\section{Recommendation 3: Encourage Departmental Control over Open Educational Resources}

'A committee is a group of the unprepared, appointed by the unwilling to do the unnecessary'. 
Many activists use the master's tools to dismantle the master's house. However, in the effort to transform our department from a traditional model of education to a more open model, I have come to believe that the master's tools can also be used to renovate the house. One way to do that is to use and adapt pre-existing mechanisms that allow departments to function and project influence. These mechanisms include departmental meetings, reports, committees, educational plans and schedules, budgets, interactions with other institutional units, and the various formal and informal policies and practices that define the department's organizational culture.

One of the mechanisms of influence that we used was the creation of our own OER committee. This may seem counterproductive; after all, aren't faculty everywhere united in their disdain for committees and their procedural swamps of policy, protocol, and paperwork? Faculty chose their discipline out of love and interest, not a desire to sit on committees. They trained to be educators and scholars and then, one day, were bewildered to find themselves serving on 8, 9, or 10 committees. How could such a universally adopted mechanism for decisionmaking be so universally despised? Possibly because committees are remarkably effective at protecting and promoting individual and departmental interests.

Consider the following scenario in which a junior faculty member proposes a significant curricular change-let's call it 'Bright Idea'-to a departmental curriculum committee. Remember, this idea can trigger resistance in two ways: first, because it is a truly bad idea; second, because the committee is structurally biased to resist any idea. Committee members learn about the proposal and imagine all the sturm und drang it promises. In what ways could this coalition of the unwilling slow down or block the Bright Idea? After serving on hundreds of committee meetings, I now recognize at least seven subtle tactics which committees use to resist change. Let's call these tactics, 'The Seven Deadly Arrows of Committees' (Table 2).

\begin{tabular}{|l|l|}
\hline First Arrow & $\begin{array}{l}\text { Populate the committee with 'laggards' or 'late majority' adopters } \\
\text { (Rogers, 2003) }\end{array}$ \\
\hline Second Arrow & Demand unreasonable amounts of evidence \\
\hline Third Arrow & $\begin{array}{l}\text { Limit discussion and hold infrequent meetings on inconvenient } \\
\text { days }\end{array}$ \\
\hline Fourth Arrow & Relegate the Bright Idea to further study \\
\hline Fifth Arrow & Declare that the Bright Idea is not part of the committee's mandate \\
\hline Sixth Arrow & Oppose motions favouring the Bright Idea. \\
\hline Seventh Arrow & $\begin{array}{l}\text { Invoke a Fear, Uncertainty, and Doubt (FUD) campaign by } \\
\text { suggesting that the Bright Idea will increase workload, threaten } \\
\text { job security, dilute program quality, waste resources, or diminish } \\
\text { academic rigour }\end{array}$ \\
\hline
\end{tabular}

Table 2: The Seven Deadly Arrows of Committees. 


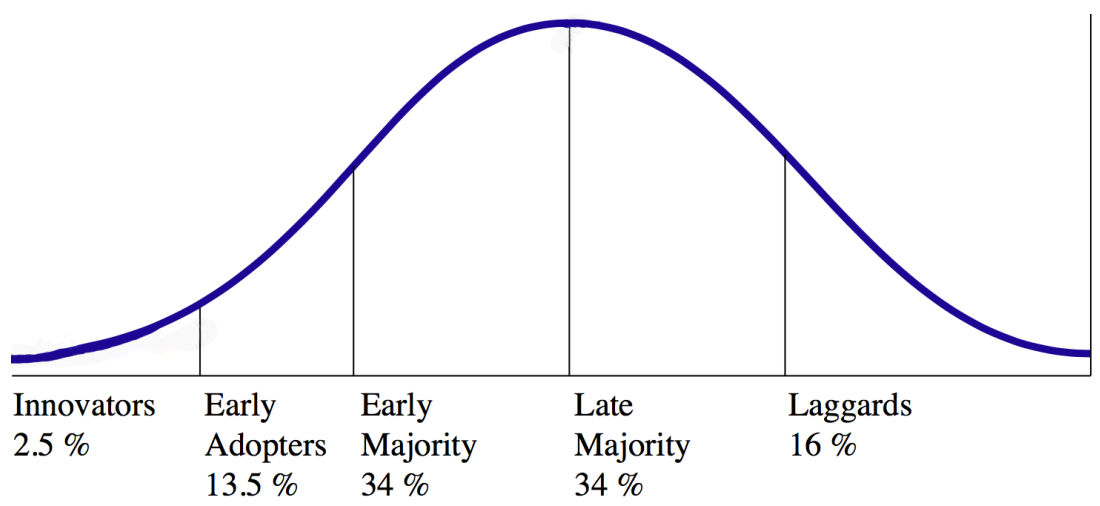

Fig. 2: Diffusion of innovation adoption curve.

This bleak destiny of bright ideas targeted for death-by-committee can be altered. To understand how, consider Rogers' (2003) diffusion of innovation theory which seeks to explain how innovations (ideas, behaviours, technologies) are adopted. When individuals in a social system, like a psychology department, are classified on the basis of their innovativeness, five normally distributed classifications emerge: innovators, early adopters, early majority, late majority, and laggards, with each category acting as an influencer for the next (Figure 2). The innovators $(2.5 \%)$ are venturesome risk-takers while the early adopters $(13.5 \%)$ are respected opinion leaders comfortable with change and uncertainty.

The curriculum committee members in our 'Bright Idea' scenario above are laggards and late majority adopters. The former are tradition-bound, conservative, and skeptical of change; the latter are change resisters who tend to adopt innovations only after successful adoption by the majority. Together, laggards and late majority adopters typically comprise $50 \%$ of a social group.

This theoretical model predicts that if a committee is strategically populated with innovators and early adopters, then there is a better chance for an innovation to be diffused through the entire social group. These two groups comprise $16 \%$ of the theoretical distribution, a number that falls very close to the $20 \%$ of our department members who currently serve on our OER committee and whom I consider change agents. Interestingly, a closer inspection of the open education developmental landmarks achieved by our psychology department (Table 1), reveals that every landmark achieved was by a member of our OER committee.

In the autumn of 2014, an interesting thing happened during a departmental meeting: I sought the department's blessings to use an open textbook for my Introduction to Psychology course. This request was without precedent as the department had an 'understanding' with a publisher to use only their Intro to Psychology textbook for at least three years. This exclusivity arrangement lowered the cost of the textbook and provided us with some scholarship money for students. Of course, using an open online textbook would cost our students 
nothing or, at most, the expense of a printed version (about $70 \%$ cheaper than the traditional textbook). The department's response was cautious and conditional: blessings would be given but evidence of the open textbook's relative efficacy should be collected. This request is reasonable but it simultaneously masks a characteristic of the pragmatic early majority adopters and the skeptical late majority adopters: interrogate new pedagogical practices and demand to be shown proof of their efficacy. In my experience, the reasonableness of this request is compromised by the observation that these same groups rarely subject their own pedagogical practices to equivalent scrutiny.

Notwithstanding this observation, the innovators and early adopters felt that data-driven arguments about the efficacy of open textbooks were important. And so several of the OER committee faculty developed a quasi-experimental research study to compare the efficacy of an Intro Psychology ${ }^{29}$ open textbook vs. our traditional textbook. ${ }^{30}$ The results of that study showed that, in terms of exam scores and qualitative student comments, the open textbook was at least as good as or better than the traditional textbook. ${ }^{31}$

Other made-in-psychology resources have further strengthened the open project including a Moodle-based OER of psychology learning objects and a PsycWiki. PsycWiki is a collaborative effort to create an open access textbook environment perpetually edited by students and faculty. This OER is modeled on wildly successful Chemistry LibreTexts library (2 million monthly visitors) developed by UC Davis' Delmar Larsen. ${ }^{32}$ Important as these resources are, it is equally important that they are the product of faculty-driven initiative and collaboration. In this way, slowly but surely, the department comes to view these open education initiatives as its own and, ironically, begins defending them as part of its 'interests.'

\section{Summary}

Since their emergence in the Medieval Period, few institutions have resisted change more effectively or enduringly than universities. Academic departments with their closed systems, dysfunctional politics, disciplinary elitism, and internal mechanisms for opposing new ideas are a significant reason for this stasis. Academic departments resist change as a defensive strategy to ensure preservation. However, a signal detection theory analysis reveals that some of this resistance is simply the result of a bias to making Type I errors and, therefore, is unwarranted. However, by encouraging a more open departmental culture, by focusing on quality OER, and by encouraging departmental control of OER, this bias can be overcome and wider adoption can begin.

Our department's open project unfolded, and is unfolding, along multiple themes including advocacy, strategic committee formation, policy proposals, in-house research, course development, and OER co-creation and sharing. Two factors assisted Psychology's journey into openness. The first was a group 
of innovators and early adopters who found themselves in an already collegial departmental culture. The second was an institutional environment where key players were supportive of Psychology's initiatives including the Office of the President, the Vice President Academic, the Dean of Arts, the University Librarian (and librarians), other like-minded academic departments, and the psychology student society. Of course, change never happens in a vacuum, and it is also important to acknowledge that a network of stakeholders outside of our institution provided moral support, inspiration, financial aid, advice, and expertise. These groups include BCcampus, ${ }^{33}$ the OERu, ${ }^{34}$ the NOBA Project, ${ }^{35}$ and OpenStax. ${ }^{36}$

Open education is a plea to the creators and illuminators of knowledge that it be shared; that it be open to co-creation, distribution, replication, modification, and integration; that collaboration and transparency be standard operating procedures; and that the barriers to knowledge access be dissolved. Inspired by this vision, several faculty members of KPU's psychology department began encouraging the opening of our department's culture, curriculum, and commitments. This was the story of the extraordinary opening of one ordinary psychology department. It is a story offered to you in the spirit of giving, perhaps the deepest act of openness imaginable.

\section{Notes}

1 Shedd, 2006: 705.

2 Atkins, Brown \& Hammond, 2007; Jhangiani \& Biswas-Diener, in press; Cape Town Open Education Declaration, 2007; National Knowledge Commission, 2007; OECD, 2007; Weller, 2013.

${ }^{3}$ Rittel \& Webber, 1973.

${ }^{4}$ Kurtz \& Snowden, 2003; Sargut \& McGrath, 2011.

${ }^{5}$ Burton, 2004; Thorp \& Goldstein, 2013.

${ }^{6}$ Meyer, 2013.

7 Peters \& Britez, 2008.

${ }^{8}$ Burke, 2011; Burke \& Litwin, 1992; Coch \& French, 1948; Dent \& Goldberg, 1999; Lewin, 1951; Prochaska, Redding \& Everts, 2009; Self \& Schraeder, 2009.

9 Burton, 2004; Kirschner, 2012; Rudolph, 1990.

${ }^{10}$ Peterson, Birdsall \& Fox, 1954.

11 Sayre, 2006: 670.

12 Jhangiani \& Dastur, 2014.

13 Jhangiani, 2015.

14 Le Grand et al., 2015

${ }^{15}$ Dastur et al., 2015

${ }^{16}$ Jhangiani et al., 2016; Peters \& Britez, 2008.

17 Arcos et al., 2015; Jhangiani et al., 2016

${ }^{18}$ Harley et al., 2010 
19 Bliss et al., 2013a; Bliss et al., 2013b; Feldstein et al., 2012; Hilton et al., 2013; Jhangiani et al., 2016.

${ }^{20}$ NOBA, n.d.

${ }^{21}$ Eyewitness Testimony and Memory Biases; Laney \& Loftus, 2016.

${ }^{22}$ Happiness: The Science of Subjective Well-Being; Diener, 2016.

${ }^{23}$ Emotional Intelligence; Brackett, Delaney \& Salovey, 2016.

${ }^{24}$ Self-Regulation and Consciousness; Baumeister, 2016.

${ }^{25}$ Memory (Encoding, Storage, Retrieval); McDermott \& Roediger, 2016.

${ }^{26}$ Evolutionary Theories in Psychology; Buss, 2016.

${ }^{27}$ Creative Commons, n.d.

${ }^{28}$ Hopper \& Davis, 1983.

29 Intro Psychology, n.d.

${ }^{30}$ Myers, 2013.

${ }^{31}$ Dastur et al., 2015.

${ }^{32}$ Chemistry LibreTexts, n.d.

${ }^{33}$ BCcampus, n.d.

${ }^{34}$ OERu, n.d.

${ }^{35}$ NOBA, n.d.

${ }^{36}$ OpenStax, n.d.

\section{References}

Arcos, B. de los, Farrow, R., Pitt, R., Perryman, L., \& Weller, M. (2015). OER Research Hub Data 2013-2015: Educators. OER Research Hub. Retrieved from https://oerresearchhub.files.wordpress.com/2015/09/educators_final_ oerrhdata.pdf

Atkins, D. E., Brown, J. S., \& Hammond, A. L. (2007). A review of the open educational resources (OER) movement: Achievements, challenges, and new opportunities. The William and Flora Hewlett Foundation, 1-84. Retrieved from http://www.hewlett.org/uploads/files/ReviewoftheOERMovement.pdf

Baumeister, R.F. (2016). Self-Regulation and consciousness. In R. BiswasDiener \& E. Diener (Eds), Noba textbook series: Psychology. Champaign, IL: DEF publishers. DOI: https://doi.org/nobaproject.com

BCcampus. (n.d.). Available at https://bccampus.ca

Bliss, T. J., Hilton, J., Wiley, D., \& Thanos, K. (2013b). The cost and quality of online open textbooks: Perception of community college faculty and students. First Monday, 18(1).

Bliss, T. J., Robinson, J., Hilton, J., \& Wiley, D. (2013a). An OER COUP: College teacher and student perceptions of Open Educational Resources. Journal of Interactive Media in Education, 1-25. http://doi.org/10.5334/2013-04

Brackett, M., Delaney, S., \& Salovey, P. (2016). Emotional intelligence. In R. Biswas-Diener \& E. Diener (Eds), Noba textbook series: Psychology. Champaign, IL: DEF publishers. DOI: https://doi.org/nobaproject.com. 
Burke, W. W. (2011). A Perspective on the Field of Organization Development and Change The Zeigarnik Effect. The Journal of Applied Behavioral Science, 47(2), 143-167.

Burke, W. W., \& Litwin, G. H. (1992). A causal model of organizational performance and change. Journal of Management, 18(3), 523-545.

Burton, R. C. (2004). Sustaining change in universities: Continuities in case studies and concepts. Tertiary Education and Management, 9(2), 99-116. http://dx.doi.org/10.7238/rusc.v2i1.250

Buss, D. M. (2016). Evolutionary theories in psychology. In R. Biswas-Diener \& E. Diener (Eds), Noba textbook series: Psychology. Champaign, IL: DEF publishers. DOI: https://doi.org/nobaproject.com

Cape Town Open Education Declaration (2007). Cape Town open education declaration: Unlocking the promise of open educational resources. Retrieved from http://www.capetowndeclaration.org/read-the-declaration

Chemistry LibreTexts. (n.d.). Available at http://chem.libretexts.org

Coch, L., \& French, J. R. P., Jr. (1948). Overcoming resistance to change. Human Relations, 1(4), 512-532.

Creative Commons. (n.d.). Available at https://creativecommons.org

Dastur, F., Le Grand, R., Jhangiani, R. S., \& Penner, K. (2015, November). Introductory psychology textbooks: The roles of online vs. print and open vs. traditional textbooks. OpenEd 2015 Conference. Vancouver, BC.

Dent, E. B., \& Goldberg, S. G. (1999). Challenging "resistance to change". The Journal of Applied Behavioral Science, 35(1), 25-41.

Diener, E. (2016). Happiness: The science of subjective well-being. In R. BiswasDiener \& E. Diener (Eds), Noba textbook series: Psychology. Champaign, IL: DEF publishers. DOI: https://doi.org/https://doi.org/nobaproject.com

Feldstein, A., Martin M., Hudson A., Warren K., Hilton J., \& Wiley D. (2010). Open textbooks and increased student access and outcomes. European Journal of Open, Distance and E-Learning, 2, 1-9.

Harley, D., Lawrence, S., Acord, S. K., \& Dixson, J. (2010). Affordable and open textbooks: An exploratory study of faculty attitudes. California Journal of Politics and Policy, 2(1). Retrieved from http://escholarship.org/uc/ item/1t8244nb

Hilton, J., Gaudet, D., Clark, P., Robinson, J., \& Wiley, D. (2013). The adoption of open educational resources by one community college math department. The International Review of Research in Open and Distance Learning, 14(4), 37-50.

Hopper, R., \& Davis, L. J. (1983). Between you and me: the professional's guide to interpersonal communication. London, UK: Longman Higher Education. Retrieved from http://www.notable-quotes.com/a/allen_fred.html

Huitt, W. G., \& Monetti, D. M. (in press). Openness and the transformation of education and schooling. In R. Biswas-Diener \& R. S. Jhangiani (Eds.), Open: The philosophy and practices that are revolutionizing education and science (pp. $\mathrm{xx}-\mathrm{xx}$ ). London: Ubiquity Press. 
International Journal of Wellbeing (IJW) (n.d.). Available at http://www.inter nationaljournalofwellbeing.org/)

Intro Psychology. (n.d.). Available at https://openstaxcollege.org/textbooks/ psychology

Jhangiani, R. (2015, May). An openness to openness: The terrifying and liberating process of disrupting higher education. Keynote presented at the 2015 Open Textbook Summit, Vancouver, BC.

Jhangiani, R. S., \& Biswas-Diener, R. (Eds.). (in press). Open: The philosophy and practices that are revolutionizing education and science. London, UK: Ubiquity Press.

Jhangiani, R., \& Dastur, F. (2014, October). Opening up psychology: Adopting open textbooks, open pedagogy, and an open philosophy in the classroom. Symposium conducted at the Society for the Teaching of Psychology's Annual Conference on Teaching, Atlanta, GA.

Jhangiani, R., Pitt, R., Hendricks, C., Key, J., \& Lalonde, C. (2016). Exploring faculty use of open educational resources at British Columbia post-secondary institutions. BCcampus Research Report. Victoria, BC: BCcampus. Retrieved from http://bccampus.ca/files/2016/01/BCFacultyUseOfOER_ final.pdf

Kerr, C. (2001). The uses of the university. (5th ed.). (p.115). Cambridge, MA: Harvard University Press.

Kirschner, A. (2012, April 13). Innovations in higher education? Hah! Chronicle of Higher Education, B6-B9. Retrieved at: http://chronicle.com/article/ Innovations-in-Higher/131424/

Kurtz, C., \& Snowden, D. (2003). The new dynamics of strategy: Sense-making in a complex-complicated World. IBM Systems Journal, 42(3), 462-83.

Laney, C. \& Loftus, E.F. (2016). Eyewitness testimony and memory biases. In R. Biswas-Diener \& E. Diener (Eds.), Noba textbook series: Psychology. Champaign, IL: DEF publishers. DOI: https://doi.org/nobaproject.com

Le Grand, R., Dastur, F., Jhangiani, R., \& Penner, K. (2015, July). Using open textbooks for teaching introductory psychology. 5th Vancouver International Conference on the Teaching of Psychology. Vancouver, BC.

Lewin, K. (1951). Field theory in social sciences. New York, NY: Harper \& Row McDermott, K.B. \& Roediger III, H.L. (2016). Memory (encoding, storage, retrieval). In R. Biswas-Diener \& E. Diener (Eds.), Noba textbook series: Psychology. Champaign, IL: DEF publishers. DOI: https://doi.org/noba project.com

Meyer, R. (2013, September 11). How gothic architecture took over the American college campus. The Atlantic. Retrieved from http://www.theatlantic. com/education/archive/2013/09/how-gothic-architecture-took-over-theamerican-college-campus/279287/

Myers, D. (2013). Psychology (10th ed.). New York, NY: Worth.

National Knowledge Commission, (2007). Report of the working group on Open Access and Open Educational Resources. New Delhi: National Knowledge 
Commission, Government of India, 3. Retrieved from http://knowledge commission.gov.in/downloads/documents/wg_open_course.pdf

NOBA. (n.d.). Available at http://nobaproject.com

OECD. (2007). Giving knowledge for free. The emergence of open educational resources. Paris: OECD Publishing.

OERu. (n.d.). Available at http://oeru.org

OpenStax. (n.d.). Available at https://openstaxcollege.org

OpenStax College. (8 December 2014). Psychology. http://cnx.org/content/ col11629/latest/

Peters, M. A., \& Britez, R. G. (2008). Introduction. In M. A. Peters \& R. G., Britez (Eds.), Open education and education for openness (pp. xvii-xxii). Rotterdam: Sense Publications.

Peterson, W. W., Birdsall, T. G., \& Fox, W. C. (1954). The theory of signal detectability. Proceedings of the IRE Professional Group on Information Theory, 4, $171-212$.

Prochaska, J. O., Redding, C. A., \& Evers, K. E. (2009). The transtheoretical model and stages of change. In R. Glanz \& K. Viswanath (Eds.), Health behavior and health education: Theory, research and practice (4th ed., pp. 97-117). San Francisco, CA: Josey Bass.

Rittel, H. W. J., \& Webber, M. M. (1973). Dilemmas in a general theory of planning. Policy Sciences, 4, 155-169. DOI: https://doi.org/10.1007/bf01405730

Rogers, E. (2003). Diffusion of Innovations (5th ed.). New York, NY: Free Press. Rudolph, F. (1990). The American college and university. Athens, GA: The University of Georgia Press.

Sargut, G., \& McGrath, R. G. (2011). Learning to live with complexity. Harvard Business Review, 89(9), 68-76.

Sayre, W. (2006). Sayings. In F.R. Shapiro (Ed.), The Yale book of quotations. (p.670). New Haven, CT: Yale University Press.

Schacter, D. L., Gilbert D. T., Wegner D. M., \& Nock, M. K. (2014). Psychology (3rd ed.). New York, NY: Worth.

Self, D. R., \& Schraeder, M. (2009). Enhancing the success of organizational change: Matching readiness strategies with sources of resistance. Leadership \& Organizational Development Journal, 30, 167-182.

Shedd, J.A. (2006). Sayings. In F.R. Shapiro (Ed.), The Yale book of quotations (p.705). New Haven, CT: Yale University Press.

Thorp, H., \& Goldstein, B. (2013). Engines of innovation: The entrepreneurial university in the Twenty-first century [2nd ed.]. Chapel Hill, NC: The University of North Carolina Press.

Weller, M. (2013). The battle for open - a perspective. Journal of Interactive Media in Education, 15. DOI: https://doi.org/10.5334/2013-15 